\title{
Adiponectin Enhances Biological Functions of Vascular Endothelial Progenitor Cells Through the mTOR-STAT3 Signaling Pathway
}

\author{
Xiaoying DONG ${ }^{1 *}$, Xia YAN ${ }^{2,3} *$, Wei ZHANG $^{4}$, Shengqiu TANG ${ }^{1}$ \\ *These authors contributed equally to this work. \\ ${ }^{1}$ College of Yingdong Agricultural Science and Engineering, Shaoguan University, Shaoguan, \\ China, ${ }^{2}$ Institute of Animal Science, Guangdong Academy of Agricultural Sciences, Guangzhou, \\ China, ${ }^{3}$ State Key Laboratory of Livestock and Poultry Breeding, Guangzhou, China, ${ }^{4}$ Institute of \\ Animal Husbandry and Veterinary, Hubei Academy of Agricultural Science, Wuhan, China
}

Received August 3, 2017

Accepted February 9, 2018

On-line May 10, 2018

\begin{abstract}
Summary
Adiponectin (APN), an adipose tissue-excreted adipokine, plays protective roles in metabolic and cardiovascular diseases. In this study, the effects and mechanisms of APN on biological functions of rat vascular endothelial progenitor cells (VEPCS) were investigated in vitro. After administrating APN in rat VEPCs, the proliferation was measured by methyl thiazolyl tetrazolium (MTT) method, the apoptotic rate was test by Flow cytometry assay, mRNA expression of B-cell lymphoma-2 (Bcl-2) and vascular endothelial growth factor (VEGF) was determined by real-time reverse transcriptase polymerase chain reaction (RT-PCR), and protein expression of mechanistic target of rapamycin (mTOR), signal transducer and activator of transcription 3 (STAT3) and phospho-STAT3 (pSTAT3) was analyzed by Western blot. It was suggested that APN promoted the optical density (OD) value of VEPCs, enhanced mRNA expression of Bcl-2 and VEGF, and inhibited cell apoptotic rate. Furthermore, protein expression of PSTAT3 was also increased in the presence of APN. Moreover, APN changed-proliferation, apoptosis and VEGF expression of VEPCs were partially suppressed after blocking the mTOR-STAT3 signaling pathway by the mTOR inhibitor XL388. It was indicated that APN promoted biological functions of VEPCs through targeting the mTOR-STAT3 signaling pathway.
\end{abstract}

\section{Key words}

Adiponectin • VEPCs • Proliferation • Apoptosis • mTOR • STAT3

\section{Corresponding author}

S. Tang, College of Yingdong Agricultural Science and Engineering, Shaoguan University, Daxue Road, Zhenjiang District, Shaoguan 512005, China. E-mail: willertang@163.com

\section{Introduction}

Adiponectin (APN), a circulating adipokine, has been known for its potent insulin-sensitizing, anti-atherosclerotic, anti-inflammatory, and anti-diabetic properties (Shibata et al. 2005, Tajtakova et al. 2010, Villarreal-Molina and Antuna-Puente 2012). In vitro, APN was previously shown to have the abilities to increase hemopoietic stem cell (HSC) proliferation (DiMascio et al. 2007) and to promote bone marrow stromal cell (BMSC) differentiation towards the osteoblastic lineage (Wu et al. 2014). Furthermore, APN could partly regulate the migration of angiogenic cells, cardiac fibroblasts, endothelial progenitor cells (EPCs) and muscle satellite cells (Chang et al. 2010, Shibata et al. 2008). Therefore, APN may play a crucial role in maintaining cell functions.

Especially, a variety of studies suggested that APN played a protective role in the cardiovascular system (Caselli et al. 2014). Plasma APN levels was believed to negatively correlate with cardiovascular disease, such as hypertension and metabolic disorders (Zhu et al. 2008). The reduction in plasma APN was responsible for hypertension-associated cardiovascular 
diseases (Kawai et al. 2013). The in vitro studies proved that APN could inhibit the activation of vascular endothelial cells by inducing nitric oxide (NO) activation, inhibiting apoptosis and promoting the repair of cells (Xu et al. 2010). Globular APN could resist vascular calcification via the inhibition of endoplasmic reticulum stress to reduce vascular smooth muscle cell (VSMC) apoptosis (Lu et al. 2015). Luo et al. (2009) found that globular APN could enhance mRNA expression of osteoprotegerin and suppress phenotype conversion of VSMCs into osteoblast by combining with the globular APN receptor 1 to slow down the development process of cardiovascular tissue lesions.

In 1997, EPCs was successfully isolated by Asahara et al. (1997). As the origins of vascular endothelial cells, EPCs played an important role in repairing the injured vascular endothelium, but their proliferative capacity was limited (Aragona et al. 2016, Matsuo et al. 2007), indicating that enhancing the proliferative ability of EPCs was a key step in improving the effects of EPC transplantation therapy. The findings in cultured EPCs have given us a clue that APN could promote cell number and stimulate the expression of the endothelial cell marker proteins Fms-like tyrosine kinase 1 (Flk-1) and cluster of differentiation 31 (CD31) (Shibata et al. 2008). However, these results only indicated that APN had the potential to improve vascular functions, but its mechanism remained unclear. Therefore, in this study, we explored the mechanism of APN in biological functions of EPCs from blood vessel, which could provide an effective method in the therapy of vascular associated diseases.

\section{Materials and Methods}

\section{Cell culture}

The rat VEPCs purchased from American Type Culture Collection (ATCC) (BNCC338120, USA) were cultured in Endothelial Cell Growth Medium 2 (EGM-2) BulletKit (Lonza, Basel, Switzerland) supplemented with $10 \%$ fetal bovine serum (FBS), and antibioticantimycotic solution (Gibco®, Life Technologies, Thermo Fisher Scientific, California, USA). VEPCs were incubated at $37{ }^{\circ} \mathrm{C}$ in a humidified atmosphere of $5 \%$ $\mathrm{CO}_{2}$ in air.

\section{Treatments}

The experiments were randomly divided into the following groups: Control, APN treatment $(1 \mu \mathrm{g} / \mathrm{ml})$,
XL388 treatment, and APN plus XL388 treatment. XL388 (a specific mTOR inhibitor) was purchased from Santa Cruz Biotechnology (2145 Delaware Ave Santa Cruz, CA, USA), and APN was purchased from Genepharma (Shanghai, China).

\section{MTT assay}

VEPCs at a density of $1.0 \times 10^{4} / \mathrm{ml}$ were collected from the cultures and replated into a 96-well plate and underwent different treatments. Cell proliferation was determined using MTT method according to the previous study (Dong et al. 2016). A microplate reader was used to measure the absorbance at $450 \mathrm{~nm}$ (Bio-Rad, Hercules, CA, USA).

\section{Flow cytometry}

A total of $2.0 \times 10^{4}$ cells were seeded onto a 96-well plate and $24 \mathrm{~h}$ later treated with APN, XL388, and APN plus XL388 for indicated times, then cell apoptotic rate was identified by Flow cytometry according to the manufacturer instructions. Cells were collected after trypsinization, and then fixed in $70 \%$ ethanol. After ethanol was removed, the samples were stained with $50 \mu \mathrm{g} / \mathrm{ml}$ fluorescein isothiocyanate (FITC), Annexin V, and propidium iodide (PI) (BD Biosciences, San Jose, CA, USA), respectively. Cell apoptotic rate was evaluated using a FACScan flow cytometry apparatus (BD Biosciences, San Jose, CA, USA).

\section{Western blot analysis}

The examination of the protein expression levels of mTOR, STAT3 and pSTAT3 was performed separately using Western blot analysis. Total protein was extracted and the protein concentration was measured according to previously published article (Dong et al. 2016). $\beta$-actin was used as an internal control. All antibodies were purchased from Santa Cruz Biotechnology, CA, USA. Band density was quantitated using Image $\mathrm{J}$ software.

\section{Gene expression analysis}

Expression of Bcl-2 and VEGF in VEPCs was determined at indicated times by RNA preparation and quantitative reverse transcription polymerase chain reaction (RT-PCR). Total cellular RNA was isolated from cells on 6-well plates using Trizol reagent following the manufacturer's instructions (Invitrogen, Carlsbad, CA, USA) and RT-PCR was performed according to the reference (Dong et al. 2016). $\beta$-actin expression was used 
as an internal control. Specific primer sequences were synthesized in BIOSUNE Biological Technology Corp (Shanghai, China), and the sequences of the primers were as follows: $\beta$-actin, 5'-CACGATGGAGGGGCCGGA CTCATC-3' (forward), 5'-TAAAGACCTCTATGCCAA CACAGT-3' (reverse); Bcl-2, 5'-CTGGTGGACAAC ATCGCTCTG-3' (forward), 5'-GGTCTGCTGACCTCA CTTGTG-3' (reverse); and VEGF, 5'-GGTGAGAGG TCTAGTTCCCGA-3' (forward), 5'-CCATGAACTTTC TGCTCTTC-3' (reverse).

\section{Statistical analysis}

Data are presented as the mean \pm standard deviation (SD). Student's two-tailed t-test was used to determine the statistical differences between the treatment groups and the control groups. $\mathrm{P}<0.05$ was considered to indicate a statistically significant difference.

\section{Results}

\section{APN stimulated the proliferation of VEPCS}

The cultured VEPCs were stimulated with APN at dose of $1 \mu \mathrm{g} / \mathrm{ml}$ for $12,24,48$ and $72 \mathrm{~h}$, and the viability was assessed by MTT assay. The experiments revealed that there was no significance between the control group and the APN-treated group at $12 \mathrm{~h}$ $(\mathrm{P}>0.05)$. Moreover, after $24 \mathrm{~h}$ of culture, APN-stimulated VEPCs had a higher proliferation rate than the non-stimulated VEPCs $(\mathrm{P}<0.05)$ (Fig. 1).

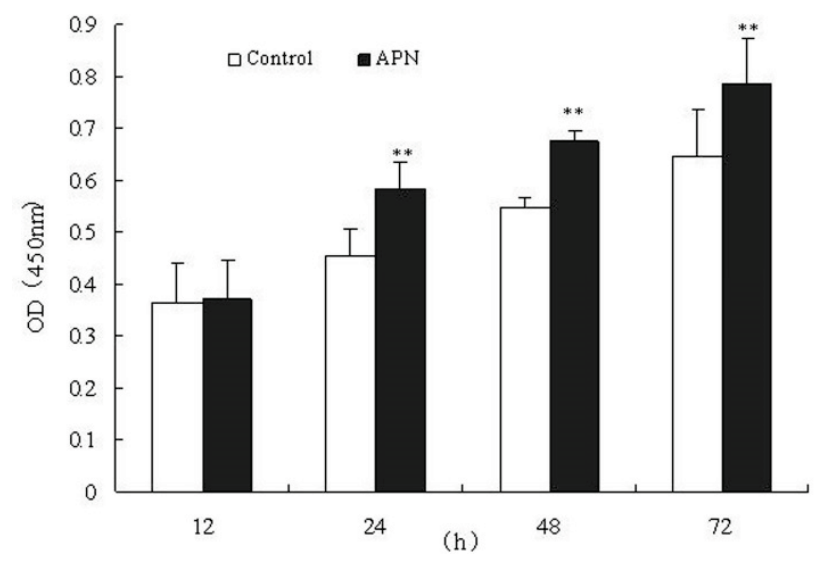

Fig. 1. APN promoted the proliferation of VEPCs. After cells were treated with $1 \mu \mathrm{g} / \mathrm{ml}$ APN for 12, 24, 48 and $72 \mathrm{~h}$, the number of viable VEPCS was determined by MTT assay. Three individual experiments were performed. Results were presented as mean \pm SD. ${ }^{*} * \mathrm{P}<0.05$ was considered as significantly different compared with the control.

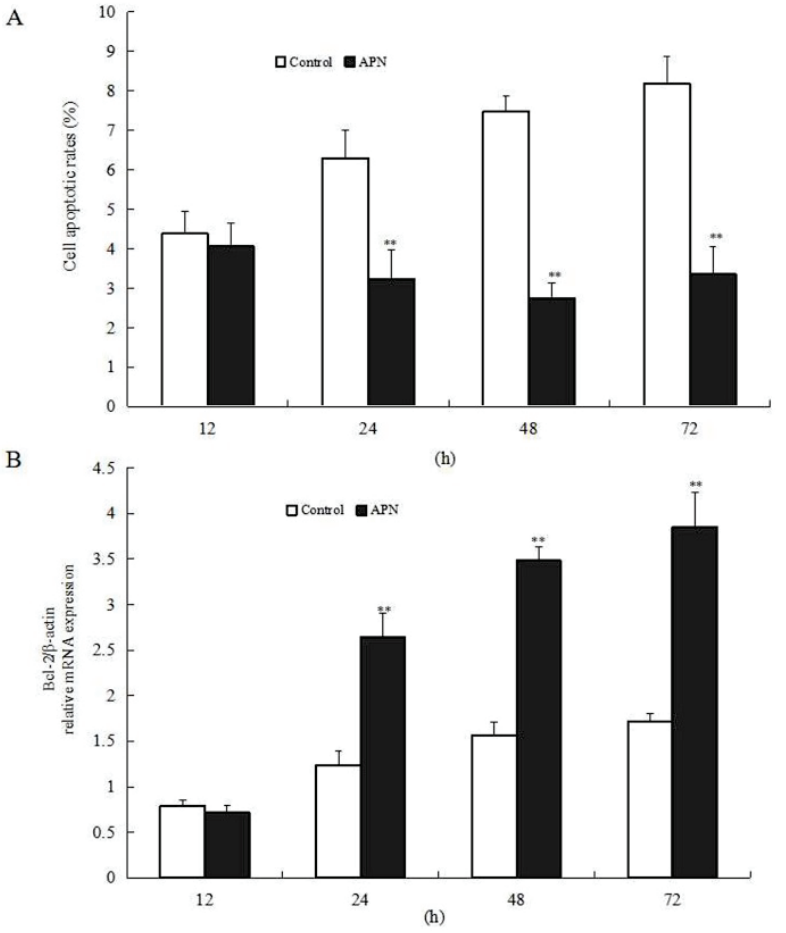

Fig. 2. APN inhibited the apoptosis of VEPCs. After cells were treated with $1 \mu \mathrm{g} / \mathrm{ml}$ APN for $12,24,48$ and $72 \mathrm{~h}$, the apoptotic rate of VEPCs was determined by Flow cytometry $(\mathbf{A})$, and $\mathrm{Bcl}-2$ expression was analyzed using RT-PCR method (B). Three individual experiments were performed. Results were presented as means $\pm \mathrm{SD}$. ${ }^{*} * \mathrm{P}<0.05$ was considered as significantly different compared with the control.

\section{APN inhibited the apoptosis of VEPCs}

APN at concentration of $1 \mu \mathrm{g} / \mathrm{ml}$ was added into VEPCs to evaluate cell apoptosis by Flow cytometry assay in vitro. The results of Flow cytometry assay demonstrated that the apoptotic rate of VEPCs was significantly decreased in the APN stimulated-group compared with the control group $(\mathrm{P}<0.05)$. The rate of apoptotic cells reached $4.06 \pm 0.58 \%, 3.24 \pm 0.72 \%$, $2.75 \pm 0.39 \%$ and $3.37 \pm 0.98 \%$ at $12,24,48$ and $72 \mathrm{~h}$, respectively, in APN stimulated-cells (Fig. 2A). To reinforce these data, the expression of the apoptosis relative factor Bcl-2 was assayed employing RT-PCR in VEPCs. The results showed that during $72 \mathrm{~h}$ of stimulation, the expression of Bcl-2 in VEPCs was higher in the presence of APN than that in VEPCs without APN stimulation, and there was an obvious significant difference between two groups following $24 \mathrm{~h}$ of stimulation $(\mathrm{P}<0.05)$ (Fig. 2B).

\section{$A P N$ enhanced the expression of VEGF in VEPCS}

Using RT-PCR method, the influence of APN on the expression of VEGF in cultured VEPCs was determined at different periods of time. As shown in 
Figure 3, VEGF was present in the supernatants of cultured VEPCs at a very low level in the control group. Moreover, the expression level of VEGF in the supernatant of VEPCs was significantly enhanced in a time-dependent manner when treated with APN at concentration of $1 \mu \mathrm{g} / \mathrm{ml}(\mathrm{P}<0.05)$.

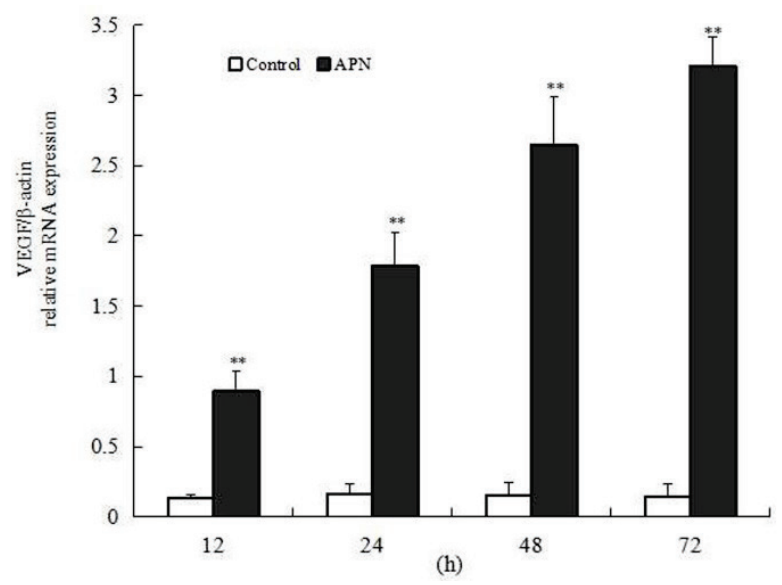

Fig. 3. APN promoted the expression of VEGF. After cells were treated with $1 \mu \mathrm{g} / \mathrm{ml}$ APN for $12,24,48$ or $72 \mathrm{~h}$, mRNA expression of VEGF was determined by RT-PCR. Three individual experiments were performed. Results were presented as mean \pm SD. ${ }^{*} * \mathrm{P}<0.05$ was considered as significantly different compared with the control.

APN activated the mTOR-STAT3 signaling pathway in VEPCs

To investigate whether APN regulated the mTOR-STAT3 signaling pathway in VEPCs, protein expression of mTOR, STAT3 and pSTAT3 was measured using Western blot analysis (Fig. 4A). It was noted that compared with the control group, there was a significant increase in pSTAT3 expression $(\mathrm{P}<0.05)$, but there were no changes in the bands of mTOR and STAT3 $(\mathrm{P}>0.05)$ in the APN-treated groups (Fig. 4B).

$A P N$ regulated biological functions of VEPCs via the mTOR-STAT3 signaling pathway

To validate the role of the mTOR-STAT3 signaling pathway played in the proliferation, apoptosis and VEGF expression of VEPCs, after blocking the signal with inhibitor XL388, we further treated VEPCs with APN at concentration of $1 \mu \mathrm{g} / \mathrm{ml}$ for $48 \mathrm{~h}$. As shown in Figure 5A, protein expression of pSTAT3 in VEPCs was evidently down-regulated following treatment with XL388, suggesting the good inhibitory efficiency of XL388 inhibitor (Fig. 5A). After treated VEPCs with XL388 for $48 \mathrm{~h}$, the proliferation of VEPCs was decreased markedly compared with the groups which was not treated with $\mathrm{XL} 388(\mathrm{P}<0.05)$. Further, there was no difference between the XL388-treated group and the XL388 plus APN-treated group ( $\mathrm{P}>0.05)$ (Fig. 5B). Subsequently, it was observed that APN inhibited the apoptotic rate of VEPCs, while inhibitor XL388 promoted it $(\mathrm{P}<0.05)$. There was also no difference in the apoptotic rate between the XL388-treated group and the XL388 plus APN-treated group (P>0.05) (Fig. 5C). Additionally, the effect of APN on inducing VEGFs could be attenuated by XL388 the inhibitor of mTOR $(\mathrm{P}<0.05)$ (Fig. 5D).

A

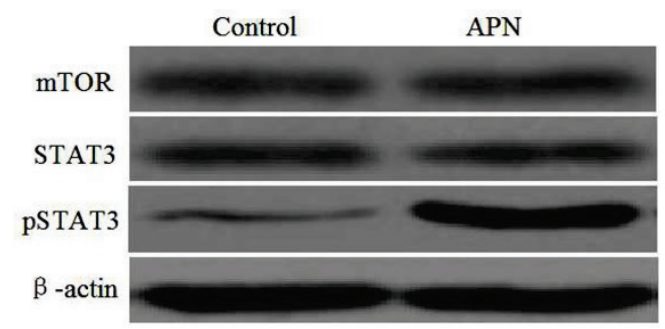

B

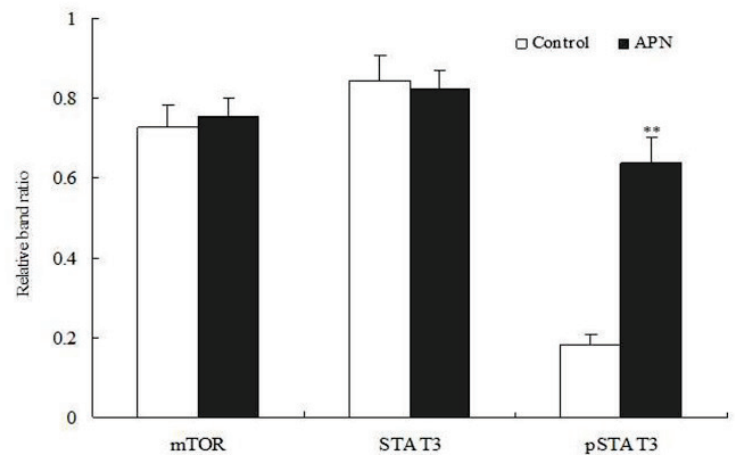

Fig. 4. The mTOR-STAT3 signaling pathway was activated by APN in VEPCs. After VEPCs were treated with $1 \mu \mathrm{g} / \mathrm{ml}$ APN for $48 \mathrm{~h}$, protein expression of mTOR, STAT3 and PSTAT3 was determined by Western blot analysis $(\mathbf{A})$. Furthermore, band relative ratio was analyzed using Image J software. Three individual experiments were performed. Results were presented as means $\pm \mathrm{SD}$. $* * \mathrm{P}<0.05$ was considered as significantly different compared with the control.

\section{Discussion}

APN, a peptide hormone secreted from the adipose tissue, regulates a number of metabolic processes as energy metabolism, cell proliferation, differentiation and apoptosis (Caselli et al. 2014, Chang et al. 2010, Shibata et al. 2008). To date, the biological role and mechanism of APN in VEPCs have not been completely assessed. Here, we investigated the effects of APN on biological functions of VEPCs, showing that APN increased cell viability and VEGF expression while decreased the apoptosis of VEPCs through the activation of the mTOR-STAT3 signaling pathway. 
A

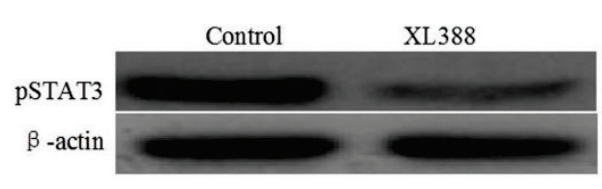

$\mathrm{C}$

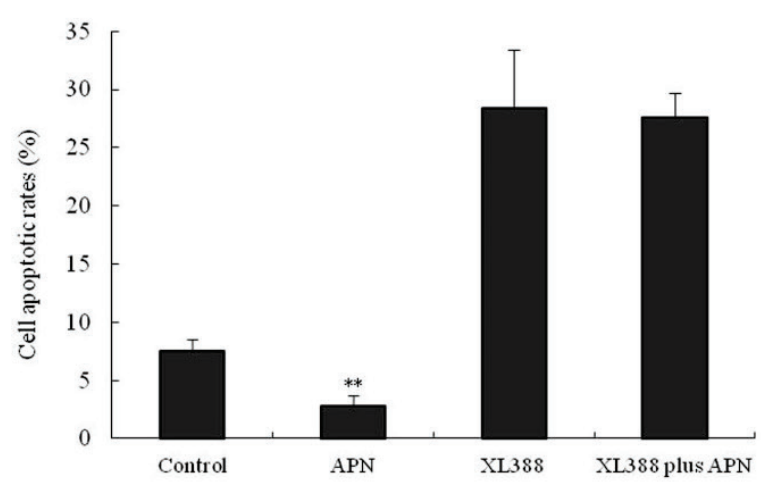

$\mathrm{B}$
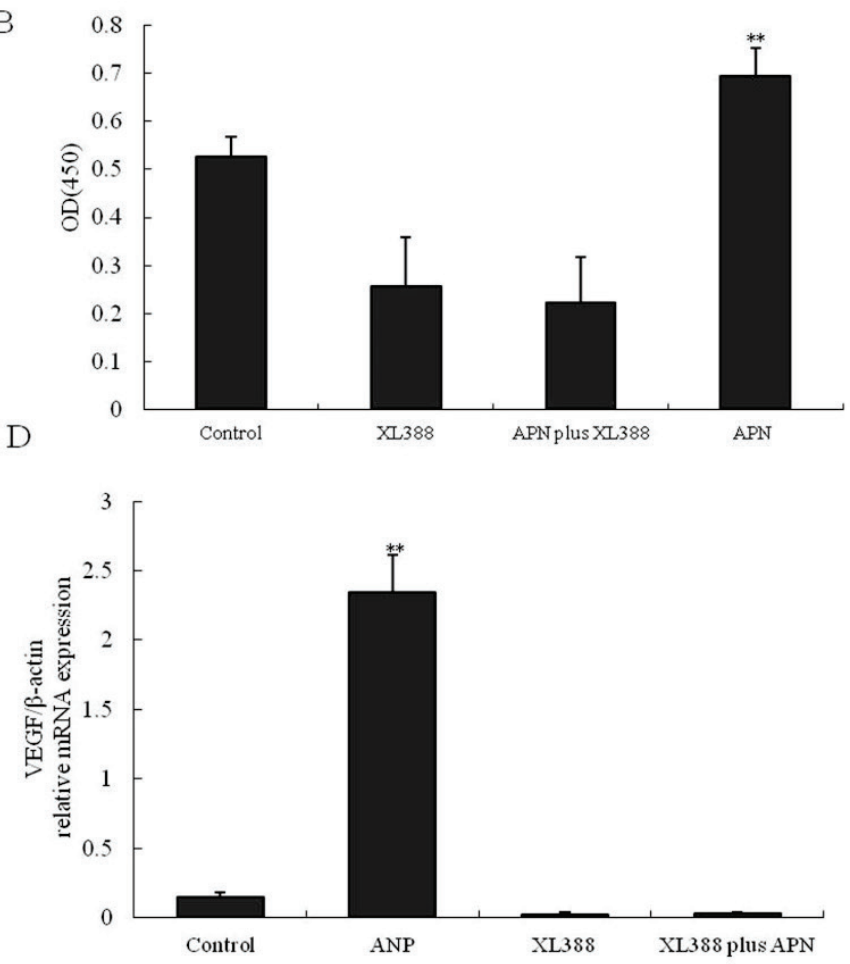

Fig. 5. The mTOR-STAT3 signaling pathway was involved in APN-induced cellular changes in VEPCs. Following the block of the mTORSTAT3 signal using XL388, protein expression of PSTAT3 was detected by Western blot analysis (A). After VEPCs were treated with APN, XL388 or APN plus XL388, cell viability was measured by MTT assay (B), the apoptotic rate was determined by Flow cytometry (C) and mRNA expression of VEGF was evaluated by RT-PCR (D). Three individual experiments were performed. Results were presented as means $\pm \mathrm{SD}$. ${ }^{* * P}<0.05$ was considered as significantly different compared with the control.

APN has been reported to play important roles in protecting different kinds of cells from injuries and may have therapeutic implications in the treatment of diseases. For instance, administration of globular APN at $25 \mathrm{mM}$ promoted EPC migration and tube formation, and dose-dependently upregulated phosphorylation of endothelial nitric oxide synthase (eNOS), Akt and augmented NO production (Huang et al. 2011). Globular APN promoted the proliferation, cell-cycle and wound repair of human bronchial epithelial cells (HBECs) via the $\mathrm{Ca}^{2+} /$ calmodulin signaling pathway, and inhibited the apoptosis of HBECs (Zhu et al. 2013). Besides, addition of globular APN increased quiescent porcine coronary artery VSMC proliferation, suggesting protection against atherosclerosis by the level of globular APN (Fuerst et al. 2012). APN was found to inhibit the growth of the murine endothelial cell line HECa 10 at concentrations from $10^{-5}$ to $10^{-12} \mathrm{M}$ (Połowinczak-Przybyłek and MełeńMucha 2009). In tumor cells, APN also exhibited potent anti-proliferative properties in human glioblastomas (Porcile et al. 2014), human hepatoma (HepG2) and breast cancer cells (Jia et al. 2016, Shrestha et al. 2014) via modulating cell cycle and apoptosis. In the present study, we also proved that APN promoted the OD values of VEPCs, indicating a proliferative response of VEPCs to APN. Additionally, compared to the control, APN significantly inhibited the apoptotic rate of VEPCs while promoted the expression of the apoptosis relative factor Bcl-2. It was suggested that APN contributed to the increased proliferation and decreased apoptosis of VEPCs.

Vascular endothelial growth factor (VEGF) is a potent mitogen for vascular endothelial cells (Mitrou et al. 2014). Many studies have shown the participation of VEGF in atherosclerosis and angiogenesis in blood vessel (Greenberg and Jin 2005, Greenberg and Jin 2013). The correlation between APN and VEGF is still controversial. In a study, APN was shown to contribute to synovitis and joint destruction in rheumatoid arthritis by stimulating VEGF in fibroblast-like synoviocytes (Choi et al. 2009). Furthermore, APN promoted VEGF-A expression through the phosphoinositide 3 kinase (PI3K)/Akt and mTOR signaling pathways in human chondrosarcoma (Lee et al. 2015). On the other hand, over-expression of adiponectin decreased production of VEGF-A in prostate cancer cells (Gao et al. 2015). Srinivasan and Sulochana (2015) ever evaluated the correlation between VEGF and APN and suggested that human retinal pigment epithelial 
cell lines exposed to APN showed the decreased mRNA and protein expression of VEGF. However, our study demonstrated that APN stimulated VEPCs to secrete VEGF.

To further explore the possible mechanism of APN in VEPCs, we attempted to investigate the involvement of the mTOR-STAT3 signaling pathway. Recent studies have further proved that APN suppressed the proliferation and migration of VSMCs and induced VSMC apoptosis by inhibiting Ras/Raf or extracellular signal regulated kinase (Erk) $1 / 2$ signaling pathway (Zhang et al. 2015). Ding et al. (2011) found that APN promoted VSMC differentiation and preserved endothelial function via activating the Akt signaling. APN increased the proliferation of the human microvascular endothelial cell line (HMEC-1) through the activation of both PI3K/Akt and ERK/MAPK pathways (Alvarez et al. 2010). APN blocked interleukin18-mediated endothelial cell death via APPL1-dependent AMP-activated protein kinase (AMPK) activation and IKK/NF-KB/PTEN suppression (Chandrasekar et al. 2008). In contrast, APN inhibited leptin-induced proliferation of preneoplastic colon epithelial cells via inhibiting leptininduced NF-kB-dependent autocrine IL-6 production and trans-IL-6 signaling (Fenton et al. 2008). In addition, APN inhibited IL-6-induced proliferation of MC-38 colon carcinoma cells by decreasing STAT-3 phosphorylation and activation (Fenton and Birmingham 2010). In a new study, APN has ever proved to regulate EPC proliferation through the mTOR/STAT3 signal (Jiang et al. 2016). Our data also supported the findings of Jiang et al. (2016) and deeply discovered that APN could increase protein expression of pSTAT3 and promoted the proliferation and VEGF expression and inhibited the apoptosis in VEPCs through increasing the activity of the mTOR-STAT3 signaling pathway.

In conclusion, the novel data obtained from our experiments indicated that stimulation VEPCs with APN increased the proliferative capacity and VEGF expression of VEPCs through the activation of the mTOR-STAT3 signaling pathway. It was indicated that amplification of the proliferation potential of APN-stimulated VEPCs might be helpful in the therapeutic interventions for cardiovascular diseases.

\section{Conflict of Interest}

There is no conflict of interest.

\section{Acknowledgements}

This research was supported by National Natural Science Foundation of China (No. 31372394), Guangdong Natural Science Foundation (Nos. 2014A030313699, 2015A030310094 and 2016A030307043), Guangdong Province Key Laboratory of Animal Nutritional Regulation (DWYYTK-18KF001), Guangdong Province Education Bureau (2017KZDXM076) and Hubei Key Laboratory of Animal Embryo and Molecular Engineering, China (2012ZD202).

\section{Abbreviations}

APN, adiponectin; Bcl-2, B-cell lymphoma-2; BMSC, bone marrow stromal cell; $\mathrm{CD} 31$, cluster of differentiation 31; EGM-2, endothelial cell growth medium 2; eNOS, endothelial nitric oxide synthase; Erk, extracellular signal regulated kinase; FBS, fetal bovine serum; Flk-1, Fms-like tyrosine kinase 1; HBECs, human bronchial epithelial cells; HepG2, human hepatoma; HMEC-1, human microvascular endothelial cell line; HSC, hemopoietic stem cell; mTOR, mechanistic target of rapamycin; MTT, methyl thiazolyl tetrazolium; NO, nitric oxide; OD, optical density; PI, propidium iodide; PI3K, phosphoinositide 3 kinase; pSTAT3, phosphoSTAT3; RT-PCR, real-time reverse transcriptase polymerase chain reaction; SD, standard deviation; STAT3, signal transducer and activator of transcription 3; VEGF, vascular endothelial growth factor; VEPCs, vascular endothelial progenitor cells; VSMC, vascular smooth muscle cell.

\section{References}

ALVAREZ G, VISITACIÓN BARTOLOMÉ M, MIANA M, JURADO-LÓPEZ R, MARTÍN R, ZULUAGA P, MARTINEZ-MARTINEZ E, NIETO ML, ALVAREZ-SALA LA, MILLÁN J, LAHERA V, CACHOFEIRO $\mathrm{V}$ : The effects of adiponectin and leptin on human endothelial cell proliferation: a live-cell study. $J$ Vasc Res 49: 111-122, 2012.

ARAGONA CO, IMBALZANO E, MAMONE F, CAIRO V, LO GULlO A, D'ASCOLA A, SARDO MA, SCURUCHI M, BASILE G, SAITTA A, MANDRAFFINO G: Endothelial progenitor cells for diagnosis and prognosis in cardiovascular disease. Stem Cells Int 2016: 8043792, 2016. 
ASAHARA T, MUROHARA T, SULLIVAN A, SILVER M, VAN DER ZEE R, LI T: Isolation of putative progenitor endothelial cells for angiogenesis. Science 275: 964-967, 1997.

CASElli C, D'AMICO A, CABIATI M, PRESCIMONE T, DEL RY S, GIANNESSI D: Back to the heart: the protective role of adiponectin. Pharmacol Res 82: 9-20, 2014.

CHANDRASEKAR B, BOYLSTON WH, VENKATACHALAM K, WEBSTER NJ, PRABHU SD, VALENTE AJ: Adiponectin blocks interleukin-18-mediated endothelial cell death via APPL1-dependent AMP-activated protein kinase (AMPK) activation and IKK/NF-kappaB/PTEN suppression. J Biol Chem 283: 24889-24898, 2008.

CHANG J, LI Y, HUANG Y, LAM KS, HOO RL, WONG WT: Adiponectin prevents diabetic premature senescence of endothelial progenitor cells and promotes endothelial repair by suppressing the p38 MAP kinase/p16INK4A signaling pathway. Diabetes 59: 2949-2959, 2010.

CHOI HM, LEE YA, LEE SH, HONG SJ, HAHM DH, CHOI SY, YANG HI, YOO MC, KIM KS: Adiponectin may contribute to synovitis and joint destruction in rheumatoid arthritis by stimulating vascular endothelial growth factor, matrix metalloproteinase-1, and matrix metalloproteinase-13 expression in fibroblast-like synoviocytes more than proinflammatory mediators. Arthritis Res Ther 11: R161, 2009.

DIMASCIO L, VOERMANS C, UQOEZWA M, DUNCAN A, LU D, WU J, SANKAR U, REYA T: Identification of adiponectin as a novel hemopoietic stem cell growth factor. $J$ Immunol 178: 3511-3520, 2007.

DING M, XIE Y, WAGNER RJ, JIN Y, CARRAO AC, LIU LS, GUZMAN AK, POWELL RJ, HWA J, RZUCIDLO EM, MARTIN KA: Adiponectin induces vascular smooth muscle cell differentiation via repression of mammalian target of rapamycin complex 1 and FoxO4. Arterioscler Thromb Vasc Biol 31: 1403-1410, 2011.

DONG X, TANG S, ZHANG W, GAO W, CHEN Y: GPR39 activates proliferation and differentiation of porcine intramuscular preadipocytes through targeting the PI3K/AKT cell signaling pathway. J Recept Signal Transduct 36: 130-138, 2016.

FENTON JI, BIRMINGHAM JM: Adipokine regulation of colon cancer: adiponectin attenuates interleukin-6-induced colon carcinoma cell proliferation via STAT-3. Mol Carcinog 49: 700-709, 2010.

FENTON JI, BIRMINGHAM JM, HURSTING SD, HORD NG: Adiponectin blocks multiple signaling cascades associated with leptin-induced cell proliferation in Apc Min/+ colon epithelial cells. Int $J$ Cancer 122: 2437-2445, 2008.

FUERST M, TAYLOR CG, WRIGHT B, TWOREK L, ZAHRADKA P: Inhibition of smooth muscle cell proliferation by adiponectin requires proteolytic conversion to its globular form. J Endocrinol 215: 107-117, 2012.

GAO Q, ZHENG J, YAO X, PENG B: Adiponectin inhibits VEGF-A in prostate cancer cells. Tumour Biol 36: 4287-4292, 2015.

GREENBERG DA, JIN K: From angiogenesis to neuropathology. Nature 438: 954-959, 2005.

GREENBERG DA, JIN K: Vascular endothelial growth factors (VEGFs) and stroke. Cell Mol Life Sci 70: 1753-1761, 2013.

HUANG PH, CHEN JS, TSAI HY, CHEN YH, LIN FY, LEU HB, WU TC, LIN SJ, CHEN JW: Globular adiponectin improves high glucose-suppressed endothelial progenitor cell function through endothelial nitric oxide synthase dependent mechanisms. J Mol Cell Cardiol 51: 109-119, 2011.

JIA Z, LIU Y, CUI S: Adiponectin induces breast cancer cell migration and growth factor expression. Cell Biochem Biophys 70: 1239-1245, 2014.

JIANG S, YANG H, LIU Z, WANG H: Adiponectin mediates endothelial progenitor cell proliferation through the mTOR-STAT3 signaling pathway. Int J Clin Exp Pathol 9: 2738-2743, 2016.

KAWAI T, OHISHI M, TAKEYA Y, ONISHI M, ITO N, YAMAMOTO K, OGURO R, KAMIDE K, RAKUGI H: Adiponectin single nucleotide polymorphism is a genetic risk factor for stroke through high pulse wave pressure: a cohort study. $J$ Atheroscler Thromb 20: 152-160, 2010.

LEE HP, LIN CY, SHIH JS, FONG YC, WANG SW, LI TM: Adiponectin promotes VEGF-A-dependent angiogenesis in human chondrosarcoma through PI3K, Akt, mTOR, and HIF- $\alpha$ pathway. Oncotarget 6: 36746-36761, 2015.

LU Y, BIAN Y, WANG Y, BAI R, WANG J, XIAO C: Globular adiponectin reduces vascular calcification via inhibition of ER-stress-mediated smooth muscle cell apoptosis. Int J Clin Exp Pathol 8: 2545-2554, 2015. 
LUO XH, ZHAO LL, YUAN LQ, WANG M, XIE H, LIAO EY: Development of arterial calcification in adiponectindeficient mice: adiponectin regulates arterial calcification. J Bone Miner Res 24: 1461-1468, 2009.

MATSUO Y, IMANISHI T, KUROI A, KITABATA H, KUBO T, HAYASHI Y, TOMOBUCHI Y, AKASAKA T: Effects of plasma adiponectin levels on the number and function of endothelial progenitor cells in patients with coronary artery disease. Circ J 71: 1376-1382, 2007.

MITROU GK, TOSIOS KI, KYROUDI A, SKLAVOUNOU A: Odontogenic keratocyst expresses vascular endothelial growth factor: an immunohistochemical study. J Oral Pathol Med 38: 470-475, 2009.

POŁOWINCZAK-PRZYBYŁEK J, MEŁEŃ-MUCHA G: The inhibitory influence of adiponectin on the growth of the murine endothelial cell line HECa 10 in vitro. Endokrynol Pol 60: 166-171, 2009.

PORCILE C, Di ZAZZO E, MONACO ML, D'ANGELO G, PASSARELLA D, RUSSO C, Di COSTANZO A, PATTAROZZI A, GATTI M, BAJETTO A, ZONA G, BARBIERI F, ORIANI G, MONCHARMONT B, FLORIO T, DANIELE A: Adiponectin as novel regulator of cell proliferation in human glioblastoma. $J$ Cell Physiol 229: 1444-1454, 2014.

SHIBATA R, SATO K, PIMENTEL DR, TAKEMURA Y, KIHARA S, OHASHI K, FUNAHASHI T, OUCHI N, WALSH K: Adiponectin protects against myocardial ischemia-reperfusion injury through AMPK- and COX-2dependent mechanisms. Nat Med 11: 1096-1103, 2005.

SHIBATA R, SKURK C, OUCHI N, GALASSO G, KONDO K, OHASHI T, SHIMANO M, KIHARA S, MUROHARA T, WALSH K: Adiponectin promotes endothelial progenitor cell number and function. FEBS Lett 582: 1607-1612, 2008.

SRINIVASAN V, SULOCHANA KN: Effect of adiponectin on expression of vascular endothelial growth factor and pigment epithelium-derived factor: an in vitro study. Indian J Pharmacol 47: 117-120, 2015.

TAJTAKOVA M, PETRASOVA D, PIDANICOVA A, GALLOVICOVA A, BLANAROVA C, PETROVICOVA J: Serum levels of leptin, adiponectin, retinol binding protein 4 and leptin/adiponectin molar ratio as another possible marker of insulin resistance in obese. Bratisl Lek Listy 111: 212-215, 2010.

VILLARREAL-MOLINA MT, ANTUNA-PUENTE B: Globular adiponectin: anti-inflammatory and cardioprotective effects. Biochimie 94: 2143-2149, 2012.

WU Y, TU Q, VALVERDE P, ZHANG J, MURRAY D, DONG LQ, CHENG J, JIANG H, RIOS M, MORGAN E, TANG Z, CHEN J: Central adiponectin administration reveals new regulatory mechanisms of bone metabolism in mice. Am J Physiol Endocrinol Metab 306: 1418-1430, 2014.

XU A, WANG Y, LAM KS, VANHOUTTE PM: Vascular actions of adipokines molecular mechanisms and therapeutic implications. Adv Pharmacol 60: 229-255, 2010.

ZHANG W, SHU C, LI Q, LI M, LI X: Adiponectin affects vascular smooth muscle cell proliferation and apoptosis through modulation of the mitofusin-2-mediated Ras-Raf-Erk1/2 signaling pathway. Mol Med Rep 12: 4703-4707, 2015.

ZHU W, CHENG KK, VANHOUTTE PM, LAM KS, XU A: Vascular effects of adiponectin: molecular mechanisms and potential therapeutic intervention. Clin Sci (Lond) 114: 361-374, 2008.

ZHU XL, QIN XQ, XIANG Y, TAN YR, QU XP, LIU HJ: Adipokine adiponectin is a potential protector to human bronchial epithelial cell for regulating proliferation, wound repair and apoptosis: comparison with leptin and resistin. Peptides 40: 34-41, 2013. 